\title{
Title:
}

\section{The influence of active phase loading on the hydrodeoxygenation (HDO) of ethylene glycol over promoted $\mathrm{MoS}_{2} / \mathrm{MgAl}_{2} \mathrm{O}_{4}$ catalysts}

\author{
Authors: \\ Trine M. H. Dabros ${ }^{1, a}$, Hendrik Kramer ${ }^{1,2}$, Martin Høj $^{1}$, Paul Sprenger ${ }^{3}$, Jan-Dierk Grunwaldt ${ }^{3}$, \\ Jostein Gabrielsen ${ }^{4}$, Anker Degn Jensen ${ }^{1 *}$. \\ ${ }^{1}$ Department of Chemical and Biochemical Engineering, Technical University of Denmark (DTU), Kgs. Lyngby, \\ 2800, Denmark. \\ ${ }^{2}$ IWT Foundation Institute of Material Science, University of Bremen, Bremen, 28359, Germany. \\ ${ }^{3}$ Institute for Chemical Technology and Polymer Chemistry, Karlsruhe Institute of Technology (KIT), Karlsruhe, \\ 76131, Germany. \\ ${ }^{4}$ Haldor Tops $\phi$ e A/S, Kgs. Lyngby, 2800, Denmark. \\ *aj@kt.dtu.dk, +45 45252841 \\ ${ }^{a}$ Current affiliation: Haldor Topsфe A/S, Kgs. Lyngby, 2800, Denmark.
}

\section{Acknowledgments:}

This work was supported by Innovation Fund Denmark (formerly The Danish Council for Strategic Research, The Programme Commission on Sustainable Energy and Environment) [Project 1305-0001 5B]. Karlsruhe Institute of Technology (KIT) and the German Research Foundation (DFG) financed the Raman spectrometer (INST 121384/731). Thomas Willum Hansen at The Center for Electron Nanoscopy (CEN) at DTU aided this work by performing transmission electron microscopy imaging.

\begin{abstract}
:
The hydrodeoxygenation (HDO) of ethylene glycol over $\mathrm{MgAl}_{2} \mathrm{O}_{4}$ supported NiMo and CoMo catalysts with around 0.8 and $3 \mathrm{wt} \%$ Mo loading was studied in a continuous flow reactor setup operated at 27 bar $\mathrm{H}_{2}$ and $400{ }^{\circ} \mathrm{C}$. A cofeed of $\mathrm{H}_{2} \mathrm{~S}$ of typically $550 \mathrm{ppm}$ was beneficial for both deoxygenation and hydrogenation and for enhancing catalyst stability. With 2.8-3.3 wt\% Mo, a total carbon based gas yield of 80-100 \% was obtained with an ethane yield of 36$50 \%$ at up to $118 \mathrm{~h}$ on stream. No ethylene was detected. A moderate selectivity towards HDO was obtained, but cracking and HDO were generally catalyzed to the same extent by the active phase. Thus, the $\mathrm{C}_{2} / \mathrm{C}_{1}$ ratio of gaseous products was 1.1-1.5 for all prepared catalysts independent on Mo loading (0.8-3.3 wt \%), but higher yields of $\mathrm{C}_{1}-\mathrm{C}_{3}$ gas products were obtained with higher loading catalysts. Similar activities were obtained from Ni and Co promoted catalysts. For the low loading catalysts (0.83-0.88 wt\% Mo), a slightly higher hydrogenation activity was observed over NiMo compared to CoMo, giving a relatively higher yield of ethane compared to ethylene. Addition of $30 \mathrm{wt} \%$ water to the ethylene glycol feed did not result in significant deactivation. Instead, the main source of deactivation was carbon deposition, which was favored at limited hydrogenation activity and thus, was more severe for the low loading catalysts.
\end{abstract}

\section{Keywords:}

Hydrodeoxygenation, bio-oil, catalytic hydropyrolysis, transportation fuel, molybdenum sulfide 


\section{Introduction}

Catalytic hydropyrolysis is an efficient process for the direct production of diesel and gasoline type fuels from solid lignocellulosic biomass such as wood and agricultural residues [1-5]. Such fuels are necessary to reach the goal of becoming independent of fossil fuels, especially in the heavy duty and aviation sector, which are not immediately moving towards electrification. However, sustainable biomass is a limited resource and cannot replace our total use of liquid fuels [6], which in 2016 was projected by the U.S. Energy Information Administration to increase from $330 \cdot 10^{6} \mathrm{TJ}$ in 2012 to $560 \cdot 10^{6} \mathrm{TJ}$ in 2040 [7]. Bio-based fuels instead show immediate potential as blend-ins for common fossil fuels, and in a longer time frame also as pure fuels.

Catalytic hydropyrolysis combines fast pyrolysis and vapor phase catalytic hydrodeoxygenation (HDO) in a single reactor [8-10], and thus eliminates the main bottleneck in traditional HDO processes; namely the need for reheating condensed pyrolysis oil, which generally causes severe coking, blocking of catalyst pores and active sites, reactor plugging, and eventually process shutdown [11,12]. Upgrading of pyrolysis oil, commonly known as bio-oil, by catalytic HDO has been extensively studied over the past decades [1,13-15]. In spite of the well-known issues related to the thermal instability of bio-oil $[12,16]$, HDO studies of model compounds remain relevant in terms of understanding the hydrogenation, deoxygenation, and other reactions, which occur during catalytic hydropyrolysis.

The cellulosic and hemi-cellulosic fraction of pyrolysis oil vapors and condensed bio-oil is largely responsible for many of its adverse fuel properties and the high propensity for coke formation [1]. Studies on pyrolysis of cellulose and sugar-derived oxygenates coupled with gas or liquid chromatography (GC or LC) and mass spectrometry (MS) have shown how the small oxygenates formed during pyrolysis can undergo secondary polymerization reactions, forming larger molecules and eventually coke [17,18]. The composition of pyrolysis vapor and condensed bio-oil is highly complex as highlighted in several reviews $[1,19,20]$. The cellulosic and hemicellulosic fraction of biomass is responsible for several oxygenate functionalities present in bio-oil, including acids, esters, alcohols, ketones, furans, and aldehydes, including sugars and derivatives hereof such as xylose, glucose, levoglucosan, cellobiosan, and more $[1,19,20]$. The complexity of real bio-oil is greatly simplified in model compound HDO studies in exchange for the opportunity to study reactions of interest in greater detail.

$\mathrm{MoS}_{2}$ based catalysts [14,15,21], as opposed to oxides such as $\mathrm{MoO}_{3}$ [22,23], are tolerant against the high hydrogen pressures needed to suppress coke formation. $\mathrm{MoS}_{2}$ based catalysts are moreover moderately priced and tolerant against sulfur, inevitably present in many types of biomass, which is a clear advantage compared to transition and noble metal based catalysts.

A potential limitation in catalytic hydropyrolysis is that the optimal temperature for pyrolysis $\left(450-550{ }^{\circ} \mathrm{C}\right)$, may not be optimal for in-situ HDO. There is a risk that the high temperature facilitates accelerated cracking into light gasses $\left(\mathrm{C}_{1}-\mathrm{C}_{4}\right)$, resulting in a lower oil yield. Thus, it is relevant to study the influence of catalyst composition on the selectivity towards HDO versus cracking in the development of HDO selective catalysts.

In this work, the conversion of ethylene glycol (a model polyol cellulose fragment) was tested over $\mathrm{Ni}$ and Co promoted $\mathrm{MoS}_{2} / \mathrm{MgAl}_{2} \mathrm{O}_{4}$ catalysts with low and high loading of the active phase. Ethylene glycol was selected as a suitable model compound for this study, as it is present in bio-oil $[19,24]$, and has a structure mimicking that of the cellulose fragments released during pyrolysis, with more than one alcohol group and a high $\mathrm{OH}$-group to carbon atom ratio. Furthermore, ethylene glycol is liquid at room temperature and thermally stable, which means that it can easily be fed as a pure compound to a continuous flow reactor operated at high temperature. The catalysts with the highest loading (NiMo\#H and $\mathrm{CoMo \# H}$ ) aimed at reaching close to monolayer coverage of Mo in the calcined oxide phase precursors. For $\mathrm{MgAl}_{2} \mathrm{O}_{4}$, monolayer coverage is achieved at a loading of approximately $4 \mathrm{Mo}$ atoms per $\mathrm{nm}^{2}$ surface area [25], which ensures optimal spreading of oxidic molybdenum species formed during calcination [26] and results in the formation of small and highly dispersed $\mathrm{MoS}_{2}$ particles during sulfidation [27]. In addition, a four times lower loading (NiMo\#L and CoMo\#L) was used to study the role of loading and the interaction between the active phase and the support during HDO. The influence of water, residence time, and time on stream (TOS) was furthermore studied, and characterization of fresh and spent catalysts with respect to composition and crystalline phases was performed to gain insights into their morphology and deactivation. 


\section{Experimental}

$\mathrm{Ni}$ - and Co-promoted $\mathrm{MoS}_{2}$ catalysts supported on $\mathrm{MgAl}_{2} \mathrm{O}_{4}$ were prepared by the incipient wetness impregnation and characterized using $\mathrm{N}_{2}$-physisorption (BET), X-ray diffraction (XRD), $\mathrm{NH}_{3}$ temperature programmed desorption ( $\mathrm{NH}_{3}$-TPD), elemental analyses, transmission electron microscopy (TEM), and Raman spectroscopy.

XRD was performed on a Huber G670 diffractometer with monochromatic $\mathrm{Cu}-\mathrm{K} \alpha 1$ radiation $\left(\lambda_{\mathrm{Cu}-\mathrm{K} \alpha 1}=\right.$ $1.54056 \AA$ ) or on a Panalytical X'pert Pro diffractometer using $\mathrm{Cu}-\mathrm{K} \alpha 1, \mathrm{Cu}-\mathrm{K} \alpha 2$, and $\mathrm{Cu}-\mathrm{K} \beta$ radiation $\left(\lambda_{\mathrm{Cu}-\mathrm{K} \alpha 2}=\right.$ $1.54443 \AA, \lambda_{\mathrm{Cu}-\mathrm{K} \beta}=1.39225 \AA$ ) in the $2 \theta$ range of $0-70^{\circ}$.

$\mathrm{NH}_{3}$-TPD was performed in a horizontal fixed bed reactor setup. The samples were first pretreated by heating at $10{ }^{\circ} \mathrm{C} / \mathrm{min}$ until $550{ }^{\circ} \mathrm{C}$ and holding for $10 \mathrm{~min}$ in a flow of $560 \mathrm{NmL} / \mathrm{min} \mathrm{N}_{2}$. The samples were then cooled in a flow of $\mathrm{N}_{2}$ until $90{ }^{\circ} \mathrm{C}$, and adsorption of $\mathrm{NH}_{3}$ was performed at $90{ }^{\circ} \mathrm{C}$ in a $580 \mathrm{NmL} / \mathrm{min}$ flow of $2550 \mathrm{ppm} \mathrm{NH} / \mathrm{N}_{2}$ for $5 \mathrm{~min}$. Adsorption was followed by flushing out excess $\mathrm{NH}_{3}$ at $90{ }^{\circ} \mathrm{C}$ for $2 \mathrm{~h}$ in $560 \mathrm{NmL} / \mathrm{min} \mathrm{N}_{2}$. Desorption was then performed in a flow of $560 \mathrm{NmL} / \mathrm{min} \mathrm{N}_{2}$, while heating at $5{ }^{\circ} \mathrm{C} / \mathrm{min}$ until $550{ }^{\circ} \mathrm{C}$ and holding for $5 \mathrm{~min}$. The outlet concentration of $\mathrm{NH}_{3}$ was determined by Fourier transform infrared (FTIR) spectroscopy using an MKS Multigas 2030 analyzer. The $\mathrm{NH}_{3}$-TPD procedure is illustrated in the Electronic Supplementary Material (ESM), Fig. S1.

The fresh catalyst properties are listed in Table 1. The composition was aimed at a high (\#H) and low (\#L) loading of active phase, with the high loading almost corresponding to a monolayer loading of 3-4 molybdenum atoms per $\mathrm{nm}^{2}$ of available support surface area [25]. A molar ratio of promoter to molybdenum was targeted at 0.3 to optimize the activity $[28,29]$. The support material was received as an amorphous mixture of $\mathrm{MgO}$ and $\mathrm{Al}_{2} \mathrm{O}_{3}\left(\mathrm{Puralox}^{\circ}\right.$ MG30 5x5, Z600134 from Sasol) and was converted to $\mathrm{MgAl}_{2} \mathrm{O}_{4}$ during calcination at $1000{ }^{\circ} \mathrm{C}$.

The prepared catalysts were sulfided in-situ prior to activity testing in a flow of $10-12 \% \mathrm{H}_{2} \mathrm{~S} / \mathrm{H}_{2}$ at $360{ }^{\circ} \mathrm{C}$. Activity testing was performed with $0.5-4.0 \mathrm{~g}$ catalyst in a fixed bed reactor setup operated at $400{ }^{\circ} \mathrm{C}$ and a total pressure of 40 barg with 27 bar $\mathrm{H}_{2}$ (balance $\mathrm{N}_{2}$ ), a co-feed of $\mathrm{H}_{2} \mathrm{~S}$ (typically $550 \mathrm{ppm}$ ), and 2.2-3.8 mol\% ethylene glycol (EG) as model compound for HDO. Gaseous products were analyzed with gas chromatography (GC), while liquid products and unconverted ethylene glycol were collected and identified by GC mass spectrometry (MS) and quantified using a $\mathrm{GC}$ flame ionization detector (FID). Gaseous products detected were $\mathrm{CH}_{4}, \mathrm{CO}, \mathrm{CO}_{2}$, ethane, ethylene, propane, and propylene. $\mathrm{CH}_{4}, \mathrm{CO}$, and $\mathrm{CO}_{2}$ are collectively referred to as cracking products, although $\mathrm{CO}_{2}$ is formed from the water gas shift reaction. Liquid products included unconverted ethylene glycol and $\mathrm{C}_{2+}$ oxygenates. The time on stream (TOS) for each activity test was up to $172 \mathrm{~h}$.

A detailed description of the catalyst preparation, support properties, $\mathrm{N}_{2}$-physisorption (BET), elemental analyses, Raman spectroscopy, activity testing, and calculations can be found in ref. [27]. The presented conversions and yields from the activity test are on a molar carbon basis. The conversion, $X$, of ethylene glycol was calculated based on the molar flow in, $F_{E G, f e e d}$, and out, $F_{E G, \text { out }}$, of the system (equation (1)). The carbon based yield, $Y$, of compound $i$ was determined from equation (2), where $F_{i}$ is molar flow rate and $v_{C, i}$ is the number of carbon atoms in compound $i$.

$X=\frac{F_{E G, \text { feed }}-F_{E G, \text { out }}}{F_{E G, \text { feed }}} \cdot 100 \%$

$Y_{i}=\frac{F_{i} \cdot v_{C, i}}{2 \cdot F_{E G, f e e d}} \cdot 100 \%$

The selectivity towards HDO relative to cracking was defined as the $\mathrm{C}_{2} / \mathrm{C}_{1}$ ratio, i.e. the ratio between the summed yield of target $\mathrm{HDO}$ products (ethane and ethylene) to the summed yield of $\mathrm{CH}_{4}, \mathrm{CO}$, and $\mathrm{CO}_{2}$.

$\frac{C_{2}}{C_{1}}=\frac{Y\left(C_{2} \mathrm{H}_{6}\right)+Y\left(C_{2} \mathrm{H}_{4}\right)}{Y\left(\mathrm{CH}_{4}\right)+Y(\mathrm{CO})+Y\left(\mathrm{CO}_{2}\right)}$

Propane and propylene formed during HDO have not been considered in this measure of HDO to cracking selectivity. As their formation from ethylene glycol relies on deoxygenation as well as $\mathrm{C}-\mathrm{C}$ bond cleavage and formation, they cannot immediately be grouped as either HDO or cracking products. The combined HDO and cracking activity is indicated by the total yield of $\mathrm{C}_{1}-\mathrm{C}_{3}$ gas products. 


\section{Results and discussion}

\subsection{XRD}

XRD was performed to verify the identity of the magnesium aluminum spinel support, and, in addition, to verify that a high dispersion of the active phase was obtained during the catalyst preparation. The calcined support material was crystalline $\mathrm{MgAl}_{2} \mathrm{O}_{4}$ with expected peaks at $2 \theta=19,31.2,36.8,44.8,55.6$, and $59.4^{\circ}$ (Fig. 1). A small peak at $2 \theta=$ $42.8^{\circ}$ indicated the presence of a small excess of $\mathrm{MgO}$. As $\gamma-\mathrm{Al}_{2} \mathrm{O}_{3}$ (as well as $\eta-\mathrm{Al}_{2} \mathrm{O}_{3}$ ) transforms into $\theta-\mathrm{Al}_{2} \mathrm{O}_{3}$ at 850-1000 ${ }^{\circ} \mathrm{C}$ [30], a comparison with $\theta-\mathrm{Al}_{2} \mathrm{O}_{3}$ was also made (Fig. 1). Despite some similarity with the $\mathrm{MgAl}_{2} \mathrm{O}_{4}$ diffractogram, $\theta-\mathrm{Al}_{2} \mathrm{O}_{3}$ was not present in the sample. A similar comparison also showed no presence of $\gamma-\mathrm{Al}_{2} \mathrm{O}_{3}$ or $\alpha-$ $\mathrm{Al}_{2} \mathrm{O}_{3}$ (forms at $>1150{ }^{\circ} \mathrm{C}[30]$ ).

$\mathrm{XRD}$ was performed on the calcined oxide phase catalyst precursors. In all cases, only $\mathrm{MgAl}_{2} \mathrm{O} 4$ was detected, suggesting that active phase precursors were present with high dispersion or possibly incorporated into the spinel structure. This was also the case for a sulfided and spent NiMo catalyst, where no other reflections besides those from the support were detected in the diffractogram. The presence of highly dispersed oxide precursor species in these catalysts, was demonstrated with Raman spectroscopy in a previous study [27], which included X-ray absorption spectroscopy (XAS) results for the oxide and sulfide phases of similar catalysts. Raman spectroscopy is used in the present work to identify the presence of $\mathrm{MoS}_{2}$ in spent sulfided CoMo and NiMo catalysts as well as to demonstrate that no bulk oxidation of the oxide phase occurred during HDO (see section 3.7).

\section{2 $\mathrm{NH}_{3}-\mathrm{TPD}$}

The total number of acid sites was measured by $\mathrm{NH}_{3}$-TPD for the calcined support and compared with that of the precursor, and a typical $\gamma-\mathrm{Al}_{2} \mathrm{O}_{3}$ support (Table 2). See the ESM, Fig. S1 and $\mathrm{S} 2$ for TPD procedure and profiles. The concentration of acid sites per unit of surface area was similar for $\mathrm{MgAl}_{2} \mathrm{O}_{4}$ and $\gamma-\mathrm{Al}_{2} \mathrm{O}_{3}$ at $\sim 1 \mu \mathrm{mol} / \mathrm{m}^{2}$. As the affinity for coke formation during HDO and hydrotreating is linked to the support acidity [31-33], the results indicate that $\mathrm{MgAl}_{2} \mathrm{O}_{4}$ may have similar propensity for coke formation as typical $\gamma-\mathrm{Al}_{2} \mathrm{O}_{3}$ supports. The spinel precursor showed the lowest concentration of acid sites per unit surface area due to the content of basic $\mathrm{MgO}$, and the highest concentration of acid sites per unit mass due to the high surface area. The concentration of acid sites per unit of surface area followed the trend: $\mathrm{MgAl}_{2} \mathrm{O}_{4} \approx \gamma-\mathrm{Al}_{2} \mathrm{O}_{3}>\mathrm{Al}_{2} \mathrm{O}_{3}-\mathrm{MgO}$, but due to the low surface area of $\mathrm{MgAl}_{2} \mathrm{O}_{4}$, the trend based per unit of mass was: $\mathrm{Al}_{2} \mathrm{O}_{3}-\mathrm{MgO}>\gamma-\mathrm{Al}_{2} \mathrm{O}_{3}>\mathrm{MgAl}_{2} \mathrm{O}_{4}$ (Table 2). A broad peak in the desorption profile for $\gamma-\mathrm{Al}_{2} \mathrm{O}_{3}$, with a shoulder between $200-280{ }^{\circ} \mathrm{C}$ (ESM, Fig. S2), could indicate that both weaker and stronger acid sites were present in $\gamma-\mathrm{Al}_{2} \mathrm{O}_{3}$, while there was a higher concentration of weaker acid sites in $\mathrm{MgAl}_{2} \mathrm{O}_{4}$.

\subsection{Activity of $\mathrm{MgAl}_{2} \mathrm{O}_{4}$}

The activity of the support ( $1.0 \mathrm{~g}$, without pre-sulfidation) was tested for ethylene glycol HDO during $52 \mathrm{~h}$ on stream with $550 \mathrm{ppm} \mathrm{H}_{2} \mathrm{~S}$ and $3.4 \mathrm{~mol} \%$ ethylene glycol in the feed at a weight hourly space velocity (WHSV) of 9 $\mathrm{g}_{\mathrm{EG}} /\left(\mathrm{g}_{\mathrm{cat}} \cdot \mathrm{h}\right)$. The average conversion was $28.3 \%$ and there was negligible activity towards cracking (forming $\mathrm{CO}$, $\mathrm{CO}_{2}$, or $\mathrm{CH}_{4}$ ) and towards $\mathrm{HDO}$ (forming ethane or ethylene) over the support, producing a total carbon gas yield of only 1.3-2.1\% ( $\leq 1.1 \%$ ethylene, $\leq 0.4 \%$ ethane, $\leq 0.9 \% \mathrm{CO}, \leq 0.4 \% \mathrm{CO}_{2}$, no $\mathrm{CH}_{4}$, and no $\mathrm{C}_{3}$ ). In the liquid products, there was a more significant yield of 2-methyl-1,3-dioxolane (2.7-5.6\%), diethylene glycol (2.5-4.5\%), and ethanol (2.7-4.4\%). The yield of methanol (0.9-1.4\%) and 4-polyethylene glycol (0.3-0.8\%) along with the remaining liquid products detected, was less significant.

The formation of 2-methyl-1,3-dioxolane, diethylene glycol, and 4-polyethylene glycol is proposed to occur via the reaction scheme shown in Fig. 2. Dehydration of ethylene glycol forms ethenol (vinyl alcohol), which is expected to restructure to its keto form, acetaldehyde, as the equilibrium constant, $K$, for this reaction is $>1$ with $\log (K)=3$ 5 at $300-600{ }^{\circ} \mathrm{C}$ (calculated using the software package HSC Chemistry v.9.4.1). Acetaldehyde can undergo acetalization with ethylene glycol to form 2 methyl-1,3-dioxolane, while di- and polyethylene glycol can form via alcohol condensation reactions

Mixed magnesium aluminum oxides are known to catalyze both dehydration and alcohol condensation reactions [34,35] and alcohol dehydration has been reported to occur via different reaction mechanisms over $\mathrm{Mg}$-rich 
and Al-rich $\mathrm{Mg}_{x} \mathrm{Al}_{y} \mathrm{O}_{z}$, with the resulting rate of dehydration being the fastest for the more acidic Al-rich samples [35].

\subsection{Influence of active phase loading and choice of promoter}

The catalysts were tested for ethylene glycol $\mathrm{HDO}$ with $550 \mathrm{ppm} \mathrm{H}_{2} \mathrm{~S}$ and 2.2-3.8 mol\% ethylene glycol in the feed at a $\mathrm{WHSV}_{\mathrm{EG}}$ of $2 \mathrm{~h}^{-1}$. The measured reaction temperature at a furnace set point of $400{ }^{\circ} \mathrm{C}$ stabilized within the first 5 $\mathrm{h}$ on stream at $408-416{ }^{\circ} \mathrm{C}$ due to the exothermic nature of HDO at the applied conditions. The ethylene glycol conversion was $90-100 \%$ (Fig. 3a), and for the higher loading catalysts (\#H), no deactivation was observed, indicating a surplus of catalyst. The TOS of CoMo\#H was extended to $118 \mathrm{~h}$ to see whether the conversion would decrease significantly below $100 \%$, indicating catalyst deactivation, but no such observation was made. A change in the selectivity was however observed, as the $\mathrm{C}_{2} / \mathrm{C}_{1}$ ratio decreased until $80 \mathrm{~h}$ on stream and then stabilized. This indicates some deactivation of the HDO activity.

The ratio of $\mathrm{HDO}$ to cracking as indicated by the $\mathrm{C}_{2} / \mathrm{C}_{1}$ ratio, was in the range of 1.1-1.5 for all catalysts with a decreasing trend over time (Fig. 3b). For the low loading catalysts (\#L), the initial $\mathrm{C}_{2} / \mathrm{C}_{1}$ ratio was $1.7-1.9$, but decreased to 1.5 within the first $2-5 \mathrm{~h}$ on stream. The independence of this ratio on the loading suggests that both HDO and cracking were equally catalyzed by the active phase without significant influence from the support.

The higher loading catalysts produced hydrogenated HDO products; no ethylene or propylene was detected (Fig. 3c). Ethane was initially produced at a yield of 40-50\%.The ethane yield of NiMo\#H was stable over time, whereas a slight linear decrease of $3.8 \%$-points of the ethane yield per hour was observed for CoMo\#H. NiMo\#L and CoMo\#L produced a mixture of ethylene, ethane, propylene, and propane, with a slightly higher hydrogenation activity of NiMo\#L. The ethane yield was 2-12\% for NiMo\#L and 2-10\% for CoMo\#L. Both catalysts experienced an initial rapid decrease down to $4 \%$ within the first 6-12 h on stream. The ethylene yield was 6-8\% for NiMo\#L and 6-10\% for CoMo\#L. At the same time, the propane yield was $1.2 \%$ for NiMo\#L and $0.7 \%$ for CoMo\#L, and the propylene yield was $2 \%$ for both catalysts.

Ni promotion is generally observed to provide better hydrogenation activity than Co promotion, particularly in the conversion of aromatic species [36-41] as known from both HDO and hydrodesulfurization (HDS). In this case, however, a rather similar activity was obtained with $\mathrm{Ni}$ and Co promotion; especially at higher active phase loadings. This is due to the nature of the reactant, ethylene glycol, which is not subject to different HDO reaction routes to the same extent as aromatic species. For aromatic species, HDO (and HDS) over Co promoted $\mathrm{MoS}_{2}$ is commonly believed to occur via the direct deoxygenation (DDO) route without aromatic ring saturation, whereas Ni promoted $\mathrm{MoS}_{2}$ is believed to favor flat ring adsorption and hydrogenation (HYD) prior to deoxygenation [38,42]. However, ethylene glycol HDO does not have the same opportunity to go through different HDO routes (see below), and the hydrogenation activity available in both the $\mathrm{Co}$ and $\mathrm{Ni}$ promoted catalysts seems sufficient at the applied hydrogen partial pressure, with a marginal better hydrogenation activity of the NiMo\#L catalyst compared to CoMo\#L.

The cracking activity was practically identical for catalysts with the same loading (ESM, Fig. S3). Low loading (\#L) catalysts produced yields of $\mathrm{CO} \approx \mathrm{CO}_{2}>\mathrm{CH}_{4}$, with the $\mathrm{CO}$ and $\mathrm{CO}_{2}$ yields being 3-5\%, and the $\mathrm{CH}_{4}$ yield being 1-3\%. High loading $(\# \mathrm{H})$ catalysts produced cracking products at similar selectivity with yields in the range of 8-14\%. Cracking is favored at higher temperatures [43], so if HDO is performed in-situ during catalytic hydropyrolysis, a catalyst with low to moderate activity should be employed. Excessive cracking leading to only gaseous products was observed during the first $\sim 20 \mathrm{~h}$ on stream by Dayton et al. [44] who performed catalytic hydropyrolysis of woody biomass using a pre-reduced commercial hydrotreating catalyst at $375{ }^{\circ} \mathrm{C}$ and 3 bar $\mathrm{H}_{2}$. Some cracking will, however, most likely occur during pyrolysis and potentially also during HDO, so it is important to consider how to utilize these by-products, for example through water gas shift and steam reforming to regain $\mathrm{H}_{2}$ for the reaction, or by subsequent production of SNG as a valuable by-product by methanation [3].

A reaction scheme for the conversion of ethylene glycol into $C_{1}, C_{2}$, and $C_{3+}$ products is suggested in Fig. 4. HDO reactions have been assumed to follow a route of consecutive dehydration and hydrogenation reactions. Ethenol is expected to be shifted via tautomerization towards its keto form, acetaldehyde, which similarly to ethenol 
can be hydrogenated to form ethanol. Acetaldehyde was detected in the gas product from ethylene glycol conversion over sulfided catalysts in other experiments, where an extended gas analysis was performed.

\subsection{Influence of water}

The sensitivity of the catalyst towards water was tested for NiMo\#H by switching the pure ethylene glycol feed with one containing $30 \mathrm{wt} \%$ water at $\sim 50 \mathrm{~h}$ on stream, while keeping the WHSV of ethylene glycol and the flow of gasses constant (Fig. 5). This corresponds to a feed partial pressure of 1.1 bar ethylene glycol and 1.6 bar $\mathrm{H}_{2} \mathrm{O}$. At full HDO of ethylene glycol, this would give a total molar $\mathrm{H}_{2} \mathrm{O} / \mathrm{H}_{2} \mathrm{~S}$ ratio of 180 , while the pure ethylene glycol feed would give $\mathrm{H}_{2} \mathrm{O} / \mathrm{H}_{2} \mathrm{~S} \sim 120$. Thus, addition of water increased the potential $\mathrm{H}_{2} \mathrm{O} / \mathrm{H}_{2} \mathrm{~S}$ ratio by a factor of $\sim 1.5$. No severe effect of water addition was observed. Addition of water only resulted in a slight deactivation over time, but the activity was overall stable, and the conversion was 99-100 \% during the entire TOS of $100 \mathrm{~h}$. The S/Mo ratio in the spent catalyst (Table 3) furthermore did not indicate oxidation of the active phase, which has been suggested as a possible cause of deactivation in HDO over $\mathrm{MoS}_{2}$ based catalysts in the presence of high water partial pressure $[45,46]$. However, the S/Mo ratio is a bulk property, which does not give information on potential minute changes of the active surface sites. For this, operando studies using advanced characterization techniques such as XAS can be used [27]. This was done in [47], where XAS coupled with modulation excitation spectroscopy (MES) was used to identify reversible S-O exchanges occurring in non-promoted and promoted $\mathrm{MoS}_{2}$ catalysts under varying $\mathrm{H}_{2} \mathrm{O} / \mathrm{H}_{2} \mathrm{~S}$ ratios. Only around $1 \%$ of the Mo atoms in a non-promoted catalyst were subject to partial oxidation, which explains why these changes cannot be detected with bulk techniques. Promotion with Ni or Co was shown to reduce this partial oxidation, in agreement with other studies [45]. Thus, sulfided NiMo and CoMo catalysts are suitable for operation in a $\mathrm{H}_{2} \mathrm{O}$ containing atmosphere, such as the one formed during HDO of bio-based feeds. In this work, it is confirmed with a time on stream activity study (Fig. 5). Note, furthermore that the structure of the support material is tolerant to water exposure, as the XRD pattern of the fresh support and spent NiMo\#H catalyst (exposed to water) are identical (Fig. $1)$.

A greater sensitivity towards changes in the $\mathrm{H}_{2} \mathrm{~S}$ feed concentration compared to variation in the $\mathrm{H}_{2} \mathrm{O}$ concentration was observed. This could indicate that the promoted catalysts are stable against water induced oxidation, while a co-feed of $\mathrm{H}_{2} \mathrm{~S}$ is necessary to ensure optimal performance, through the adsorption of $\mathrm{SH}$ groups at the active surface sites $[27,37,48,49]$. However, since the experiments were performed at $100 \%$ ethylene glycol conversion, it is difficult to conclude whether the entire catalyst bed was utilized and therefore, any deactivation induced by water could be more severe than indicated here.

It has previously been shown for promoted $\mathrm{MoS}_{2}$ catalysts with 2.8-3.3 wt\% Mo that a co-feed of $\mathrm{H}_{2} \mathrm{~S}$ is necessary to ensure a high activity and selectivity towards HDO [27]. This observation has now been confirmed for low loading catalysts with 0.8-0.9 wt\% Mo (ESM, Fig. S4). The CoMo\#H catalyst, which was exposed to $550 \mathrm{ppm}$ $\mathrm{H}_{2} \mathrm{~S}$ for $118 \mathrm{~h}$ on stream, was subsequently exposed to decreasing concentrations of $\mathrm{H}_{2} \mathrm{~S}$ ( $28 \mathrm{~h}$ with $240 \mathrm{ppm}$ and then $16 \mathrm{~h}$ with $<5 \mathrm{ppm})$. As expected, a decrease in the $\mathrm{H} 2 \mathrm{~S}$ level resulted in a poorer deoxygenation and hydrogenation activity (Table S1).

\subsection{Influence of residence time}

The WHSV of ethylene glycol was increased to allow for studying the deactivation behavior at less than $100 \%$ conversion for the NiMo\#H catalyst (Fig. 6 and Fig. 7). The activity at the initial ethylene glycol WHSV of $2 \mathrm{~h}^{-1}$ (Fig. 3) was compared with the WHSV of 9 and $18 \mathrm{~h}^{-1}$, which was obtained by decreasing the catalyst mass from 4.0 $\mathrm{g}$ to $1.0 \mathrm{~g}$ and $0.5 \mathrm{~g}$, respectively. The conversion decreased to below $90 \%$ at $\mathrm{WHSV}_{\mathrm{EG}}=18 \mathrm{~h}^{-1}$, which allowed for detection of catalyst deactivation (Fig. 6).

The overall product distribution from NiMo\#H was similar for all three WHSV levels with the gas product yield based ratio of $\left(\mathrm{C}_{1}+\mathrm{C}_{2}+\mathrm{C}_{3}\right) / \mathrm{C}_{1}$ being 3 . The $\mathrm{C}_{2} / \mathrm{C}_{1}$ ratio, however, increased with increasing WHSV, being in the range of 1.2-1.5, 1.3-1.6, and 1.6-2.0 for $\mathrm{WHSV}_{\mathrm{EG}}=2$, 9, and $18 \mathrm{~h}^{-1}$, respectively (Fig. 7a). The gas product yields decreased with increasing WHSV (Fig. 7b), as expected due to the corresponding decrease in residence time. Mainly the formation of ethane and ethylene decreased over time, as can be seen from the comparison of the average yields at 5-15 and 30-40 h on stream in Fig. $7 \mathrm{~b}$. 
The concentration of unsaturated HDO products (ethylene and propylene) increased at higher WHSV, indicating insufficient hydrogenation activity, due to a lower amount of active phase and due to deactivation over time, similar to what was observed for the lower loading catalysts. At $\mathrm{WHSV}_{\mathrm{EG}}=9 \mathrm{~h}^{-1}$, the ratio of ethane to ethylene was 4-5 at TOS $>5.5 \mathrm{~h}$, and that of propane to propylene was 1 . At $\mathrm{WHSV}_{\mathrm{EG}}=18 \mathrm{~h}^{-1}$, the ethane to ethylene ratio was $1.2-1.4$, and propylene was the only $\mathrm{C}_{3}$ gas product detected.

In short, catalyst deactivation was observed at high space velocity. This is in line with the observations from section 3.4, showing that a low active phase loading (corresponding to a high space velocity over the lower loading of active phases) led to lower hydrogenation activity and deactivation. In industrial hydrotreating, a low space velocity around $1-5 \mathrm{~h}^{-1}[50]$ is typically applied along with a high hydrogen pressure $[51,52]$ to ensure a high degree of heteroatom removal, while minimizing the risk of local hydrogen depletion and coking at the catalyst surface. It can therefore be concluded that low space velocities should be applied to maintain optimal catalyst performance, while a high space velocity can be applied in studies, where deactivation over time is to be studied.

\subsection{Spent catalyst characterization}

The composition of the spent catalysts (Table 3) was approximately the same as the fresh catalysts (Table 1) in terms of the molar ratio of $\mathrm{Ni} / \mathrm{Mo}$ and $\mathrm{Co} / \mathrm{Mo}$. Si and $\mathrm{Fe}$ impurities (from the $\mathrm{SiC}$ dilution and the supporting steel wool) constituted 0.02-0.06 wt $\%$ of the spent samples. Taking into account the time on stream for each activity test, the carbon deposition was more severe on the lower loading catalysts compared to the higher loading catalysts (Table 3 ). This property was ascribed to the lower hydrogenation activity and greater exposure of the acidic support, when the active phase loading was low. The spent support (see section 3.3), had an Al/Mg ratio of 1.86 (same as in the fresh state), and the carbon deposition $(\mathrm{C} / \mathrm{TOS}=0.08 \mathrm{wt} \% / \mathrm{h})$ was similar to that of the low loading catalysts. Dark-field TEM images of the spent CoMo\#H sample (ESM, Fig. S5) indicated that the active Co-MoS 2 phase was dominantly present as small ( $\sim 5 \mathrm{~nm}$ long) monolayer slabs with very high dispersion. This is in agreement with a TEM particle size distribution performed for a similar catalyst: a freshly sulfided NiMo catalyst with $3.33 \mathrm{wt} \%$ Mo and $0.66 \mathrm{wt} \%$ $\mathrm{Ni}$, which showed an average slab length of $4.3 \pm 2.8 \mathrm{~nm}$ and a mean stacking of 1.2 [27].

The spent higher loading catalysts showed similar Raman spectra (Fig. 8) with characteristic $\mathrm{MoS}_{2}$ Raman bands at 381 and $407 \mathrm{~cm}^{-1}$ with a smaller peak at $451 \mathrm{~cm}^{-1}$ [53,54]. The peaks at 194 and $229 \mathrm{~cm}^{-1}$ could possibly originate from the presence of $\mathrm{MoS}_{3}$ [55], but a peak at $530 \mathrm{~cm}^{-1}$ was not observed to support this. The Raman bands of tetrahedrally coordinated $\mathrm{MoO}_{4}{ }^{2-}$ entities, which were observed for the fresh catalysts [27], were not present for the sulfided and spent catalysts (Fig. 8). Furthermore, no peaks were associated with either bulk oxide or sulfide phases of $\mathrm{Ni}$ or $\mathrm{Co}$ [27]. The absence of oxide phases suggests that the prepared catalysts were stable against oxidation at the applied conditions. Additionally, $\mathrm{MgAl}_{2} \mathrm{O}_{4}$ was stable against water, as seen from the XRD diffractogram of the spent NiMo\#H sample, which was exposed to water (Fig. 1). In HDO, this is a clear advantage compared to the commonly applied $\gamma-\mathrm{Al}_{2} \mathrm{O}_{3}$, which may form boehmite upon water exposure [51,56].

Carbon deposition on the spent catalysts was clearly evident from the Raman spectra (Fig. 8). The sharp peak at $1600 \mathrm{~cm}^{-1}$ corresponds to crystalline carbon with an ideal graphite lattice ( $\mathrm{G}$ band), while the broader peaks at $1200-1400 \mathrm{~cm}^{-1}$ correspond to a distorted lattice [57,58]. Overall, due to the comparatively sharp carbon bands and the strong presence of the $\mathrm{G}$ band, the observed carbon species seem crystalline and mostly graphite-like. Consequently, it is proposed to choose a catalyst with good hydrogenation activity, such as Ni-MoS 2 , and operate at moderate to high hydrogen pressure to minimize carbon deposition. As support acidity contributes markedly to the coke formation [31-33], it could be considered to increase the $\mathrm{Mg} / \mathrm{Al}$ ratio of $\mathrm{MgAl}_{2} \mathrm{O}_{4}$ to lower the acidity.

\section{Conclusions}

The various sulfided NiMo and CoMo catalysts showed a good catalytic performance in the HDO of ethylene glycol as model polyol compound for the more reactive cellulosic fraction of pyrolysis vapor and bio-oil. By varying the Mo loading from slightly below a monolayer (2.83-3.28 wt \%) to a four times lower loading (0.83-0.88 wt $\%$ ), it was shown that these catalysts produced $\mathrm{C}_{1}-\mathrm{C}_{3}$ gas products with $\mathrm{HDO}$ and cracking reactions being equally catalyzed by the active phase. As a result, the $\mathrm{C}_{2} / \mathrm{C}_{1}$ ratio was 1.1-1.5 independent of catalyst loading. A higher catalyst loading did however enhance the hydrogenation activity, which in turn also resulted in lower carbon deposition on the spent 
catalysts, possibly masked by the high conversion and incomplete utilization of the catalyst bed at an ethylene glycol WHSV of $2 \mathrm{~h}^{-1}$, a temperature of $400{ }^{\circ} \mathrm{C}, 27 \mathrm{bar} \mathrm{H}_{2}$, and a co-feed of $550 \mathrm{ppm} \mathrm{H}_{2} \mathrm{~S} . \mathrm{MgAl}_{2} \mathrm{O}_{4}$ was shown to catalyze dehydration and coupling reactions, which was ascribed to the presence of acid sites, but no significant HDO or cracking was observed.

$\mathrm{Ni}$ and Co promotion gave rise to similar activities and product distributions at the applied conditions, but the hydrogenation activity seemed to be higher over NiMo. A co-feed of $\mathrm{H}_{2} \mathrm{~S}$ was necessary to avoid accelerated deactivation. Deactivation was not accelerated by addition of $30 \mathrm{wt} \%$ water to the ethylene glycol feed, but carbon deposition, associated with lack of hydrogenation activity, was notable. At an ethylene glycol WHSV of $2 \mathrm{~h}^{-1}$, a conversion $>90 \%$ could be obtained for both low and high loading NiMo and CoMo catalysts. An increase in the ethylene glycol WHSV from 2 to $18 \mathrm{~h}^{-1}$ was necessary to bring the conversion below $90 \%$, and a high WHSV should be applied in further work, if deactivation and reactivation mechanisms are to be studied further.

\section{Electronic Supplementary Material:}

The supplementary material contains details on $\mathrm{NH}_{3}$-TPD, additional activity test results, and TEM images.

\section{Conflict of Interest:}

The authors declare that they have no conflict of interest. 


\section{References:}

[1] T.M.H. Dabros, M.Z. Stummann, M. Høj, P.A. Jensen, J.-D. Grunwaldt, J. Gabrielsen, P.M. Mortensen, A.D. Jensen, Transportation fuels from biomass fast pyrolysis, catalytic hydrodeoxygenation, and catalytic fast hydropyrolysis, Prog. Energy Combust. Sci. 68 (2018) 268-309. doi:10.1016/j.pecs.2018.05.002.

[2] M.Z. Stummann, M. Høj, C.B. Schandel, A.B. Hansen, P. Wiwel, J. Gabrielsen, P.A. Jensen, A.D. Jensen, Hydrogen assisted catalytic biomass pyrolysis. Effect of temperature and pressure, Biomass and Bioenergy. 115 (2018) 97-107. doi:10.1016/j.biombioe.2018.04.012.

[3] T.-V. Nguyen, L.R. Clausen, Thermodynamic analysis of polygeneration systems based on catalytic hydropyrolysis for the production of bio-oil and fuels, Energy Convers. Manag. 171 (2018) 1617-1638. doi:10.1016/j.enconman.2018.06.024.

[4] M.Z. Stummann, A.B. Hansen, L.P. Hansen, B. Davidsen, S.B. Rasmussen, P. Wiwel, J. Gabrielsen, P.A. Jensen, A.D. Jensen, M. Høj, Catalytic hydropyrolysis of biomass usingmolybdenum sulfide based catalyst. Effect of promoters, Energy \& Fuels. 33 (2019) 1302-1313. doi:10.1021/acs.energyfuels.8b04191.

[5] M.Z. Stummann, M. Høj, B. Davidsen, A.B. Hansen, L.P. Hansen, P. Wiwel, C.B. Schandel, J. Gabrielsen, P.A. Jensen, A.D. Jensen, Effect of the catalyst in fluid bed catalytic hydropyrolysis, Catal. Today. In press (2019). doi:10.1016/j.cattod.2019.01.047.

[6] J. Popp, Z. Lakner, M. Harangi-Rákos, M. Fári, The effect of bioenergy expansion: Food, energy, and environment, Renew. Sustain. Energy Rev. 32 (2014) 559-578. doi:10.1016/j.rser.2014.01.056.

[7] Independent Statistics \& Analysis - U.S. Energy Information Administration, International energy outlook 2016 - DOE/EIA-0484, 2016. https://www.eia.gov/outlooks/ieo/pdf/0484(2016).pdf (accessed July 7, 2017).

[8] F.L.P. Resende, Recent advances on fast hydropyrolysis of biomass, Catal. Today. 269 (2016) 148-155. doi:10.1016/j.cattod.2016.01.004.

[9] T.L. Marker, L.G. Felix, M.B. Linck, M.J. Roberts, Integrated hydropyrolysis and hydroconversion $\left(\mathrm{IH}^{2}\right)$ for the direct production of gasoline and diesel fuels or blending components from biomass , part 1: Proof of principle testing, Environ. Prog. Sustain. Energy. 31 (2012) 191-199. doi:10.1002/ep.

[10] T.L. Marker, L.G. Felix, M.B. Linck, M.J. Roberts, P. Ortiz-toral, J. Wangerow, Integrated hydropyrolysis and hydroconversion $\left(\mathrm{IH}^{2}\right)$ for the direct production of gasoline and diesel fuels or blending components from biomass , part 2: Continuous testing, Environ. Prog. Sustain. Energy. 00 (2013) 1-7. doi:10.1002/ep.

[11] W. Baldauf, U. Balfanz, M. Rupp, Upgrading of flash pyrolysis oil and utilization in refineries, Biomass and Bioenergy. 7 (1994) 237-244. doi:10.1016/0961-9534(94)00065-2.

[12] D.C. Elliott, T.R. Hart, G.G. Neuenschwander, L.J. Rotness, A.H. Zacher, Catalytic hydroprocessing of biomass fast pyrolysis bio-oil to produce hydrocarbon products, Environ. Prog. Sustain. Energy. 28 (2009) 441-449. doi:10.1002/ep.10384.

[13] E. Furimsky, Catalytic hydrodeoxygenation, Appl. Catal. A Gen. 199 (2000) 147-190. doi:10.1016/S0926860X(99)00555-4.

[14] E. Furimsky, Hydroprocessing challenges in biofuels production, Catal. Today. 217 (2013) 13-56. doi:10.1016/j.cattod.2012.11.008.

[15] H. Wang, J. Male, Y. Wang, Recent advances in hydrotreating of pyrolysis bio-oil and its oxygen-containing model compounds, ACS Catal. 3 (2013) 1047-1070. doi:10.1021/cs400069z.

[16] T. Cordero-Lanzac, R. Palos, J.M. Arandes, P. Castaño, J. Rodríguez-Mirasol, T. Cordero, J. Bilbao, Stability of an acid activated carbon based bifunctional catalyst for the raw bio-oil hydrodeoxygenation, Appl. Catal. B Environ. 203 (2017) 389-399. doi:10.1016/j.apcatb.2016.10.018. 
[17] J. Zhang, M.W. Nolte, B.H. Shanks, Investigation of primary reactions and secondary effects from the pyrolysis of different celluloses, ACS Sustain. Chem. Eng. 2 (2014) 2820-2830. doi:10.1021/sc500592v.

[18] M.R. Hurt, J.C. Degenstein, P. Gawecki, D.J. Borton II, N.R. Vinueza, L. Yang, R. Agrawal, W.N. Delgass, F.H. Ribeiro, H.I. Kentta, On-line mass spectrometric methods for the determination of the primary products of fast pyrolysis of carbohydrates and for their gas-phase manipulation, Anal. Chem. 85 (2013) 1092710934. doi:10.1021/ac402380h.

[19] K. Routray, K.J. Barnett, G.W. Huber, Hydrodeoxygenation of pyrolysis oils, Energy Technol. 5 (2017) 8093. doi:10.1002/ente.201600084.

[20] D.A. Ruddy, J.A. Schaidle, J.R. Ferrell III, J. Wang, L. Moens, J.E. Hensley, Recent advances in heterogeneous catalysts for bio-oil upgrading via "ex situ catalytic fast pyrolysis": catalyst development through the study of model compounds, Green Chem. 16 (2014) 454-490. doi:10.1039/c3gc41354c.

[21] A.E. Coumans, E.J.M. Hensen, A real support effect on the hydrodeoxygenation of methyl oleate by sulfided NiMo catalysts, Catal. Today. 298 (2017) 181-189. doi:10.1016/j.cattod.2017.04.051.

[22] V.M.L. Whiffen, K.J. Smith, Hydrodeoxygenation of 4-methylphenol over unsupported MoP, $\mathrm{MoS}_{2}$, and $\mathrm{MoO}_{\mathrm{x}}$ catalysts, Energy \& Fuels. 24 (2010) 4728-4737. doi:10.1021/ef901270h.

[23] T. Prasomsri, M. Shetty, K. Murugappan, Y. Román-Leshkov, Insights into the catalytic activity and surface modification of $\mathrm{MoO}_{3}$ during the hydrodeoxygenation of lignin-derived model compounds into aromatic hydrocarbons under low hydrogen pressures, Energy Environ. Sci. 7 (2014) 2660-2669. doi:10.1039/c4ee00890a.

[24] A. Oasmaa, D.C. Elliott, J. Korhonen, Acidity of biomass fast pyrolysis bio-oils, Energy \& Fuels. 24 (2010) 6548-6554. doi:10.1021/ef100935r.

[25] S. Houssenbay, E. Payen, S. Kasztelan, J. Grimblot, Oxidic precursors of molybdena supported on nickel and magnesium aluminate hydrotreating catalysts, Catal. Today. 10 (1991) 541-560. doi:10.1016/09205861(91)80038-B.

[26] S. Braun, L.G. Appel, V.L. Camorim, M. Schmal, Thermal spreading of $\mathrm{MoO}_{3}$ onto silica supports, J. Phys. Chemstry B. 104 (2000) 6584-6590. doi:10.1021/jp000287m.

[27] T.M.H. Dabros, A. Gaur, D.G. Pintos, P. Sprenger, M. Høj, T.W. Hansen, F. Studt, J. Gabrielsen, J.D. Grunwaldt, A.D. Jensen, Influence of $\mathrm{H}_{2} \mathrm{O}$ and $\mathrm{H}_{2} \mathrm{~S}$ on the composition, activity, and stability of sulfided Mo, CoMo, and NiMo supported on $\mathrm{MgAl}_{2} \mathrm{O}_{4}$ for hydrodeoxygenation of ethylene glycol, Appl. Catal. A Gen. 551 (2018) 106-121. doi:10.1016/j.apcata.2017.12.008.

[28] H. Topsøe, B.S. Clausen, F.E. Massoth, Cataltsis - Science and Technology. Hydrotreating catalysis, Volume 11, Springer-Verlag, Berlin Heidelberg, Germany, 1996.

[29] L. Medici, R. Prins, The influence of chelating ligands on the sulfidation of $\mathrm{Ni}$ and $\mathrm{Mo}$ in $\mathrm{NiMo} / \mathrm{SiO}_{2}$ hydrotreating catalysts, J. Catal. 163 (1996) 38-49. doi:10.1006/jcat.1996.0303.

[30] I. Chorkendorff, J.W. Niemantsverdriet, Conceopts of modern catalysis and kinetics, 2nd ed., Wiley-VCH Verlag GmbH \& Co. KGaA, Weinheim, 2007.

[31] A. Popov, E. Kondratieva, J.M. Goupil, L. Mariey, P. Bazin, J.P. Gilson, A. Travert, F. Maugé, Bio-oils hydrodeoxygenation: Adsorption of phenolic molecules on oxidic catalyst supports, J. Phys. Chem. C. 114 (2010) 15661-15670. doi:10.1021/jp101949j.

[32] A. Centeno, E. Laurent, B. Delmon, Influence of the support of CoMo sulfide catalysts and of the addition of potassium and platinum on the catalytic performances for the hydrodeoxygenation ofcarbonyl, carboxyl, and guaiacol-type molecules, J. Catal. 154 (1995) 288-298. doi:10.1006/jcat.1995.1170. 
[33] S. Echeandia, P.L. Arias, V.L. Barrio, B. Pawelec, J.L.G. Fierro, Synergy effect in the HDO of phenol over $\mathrm{Ni}-\mathrm{W}$ catalysts supported on active carbon: Effect of tungsten precursors, Appl. Catal. B Environ. 101 (2010) 1-12. doi:10.1016/j.apcatb.2010.08.018.

[34] H. Knözinger, R. Köhne, The dehydration of alcohols over alumina. I. The reaction scheme, J. Catal. 5 (1966) 264-270. doi:10.1016/S0021-9517(66)80007-6.

[35] V. Díez, C.R. Aspesteguía, J.I.D. Cosimo, Effect of the chemical composition on the catalytic performance of $\mathrm{Mg}_{\mathrm{y}} \mathrm{AlO}_{\mathrm{x}}$ catalysts for alcohol elimination reactions, J. Catal. 215 (2003) 220-233. doi:10.1016/S00219517(03)00010-1.

[36] V.N. Bui, D. Laurenti, P. Afanasiev, C. Geantet, Hydrodeoxygenation of guaiacol with CoMo catalysts. Part I: Promoting effect of cobalt on HDO selectivity and activity, Appl. Catal. B Environ. 101 (2011) 239-245. doi:10.1016/j.apcatb.2010.10.025.

[37] O.İ. Şenol, E.-M. Ryymin, T.-R. Viljava, A.O.I. Krause, Effect of hydrogen sulphide on the hydrodeoxygenation of aromatic and aliphatic oxygenates on sulphided catalysts, J. Mol. Catal. A Chem. 277 (2007) 107-112. doi:10.1016/j.molcata.2007.07.033.

[38] C. Bouvier, Y. Romero, F. Richard, S. Brunet, Effect of $\mathrm{H}_{2} \mathrm{~S}$ and $\mathrm{CO}$ on the transformation of 2-ethylphenol as a model compound of bio-crude over sulfided Mo-based catalysts: propositions of promoted active sites for deoxygenation pathways based on an experimental study, Green Chem. 13 (2011) 2441-2451. doi:10.1039/c1gc15181a.

[39] R. Prins, Chapter 13.2: Hydrotreating, in: Handbook of Heterogeneous Catalysis: Online, Wiley-VCH Verlag GmbH \& Co. KGaA, 2008: pp. 2695-2718. doi:10.1002/9783527610044.hetcat0137.

[40] V.O.O. Gonçalves, S. Brunet, F. Richard, Hydrodeoxygenation of cresols over $\mathrm{Mo} / \mathrm{Al}_{2} \mathrm{O}_{3}$ and $\mathrm{CoMo} / \mathrm{Al}_{2} \mathrm{O}_{3}$ sulfided catalysts, Catal. Letters. 146 (2016) 1562-1573. doi:10.1007/s10562-016-1787-5.

[41] E. Schachtl, J.S. Yoo, O.Y. Gutiérrez, F. Studt, J.A. Lercher, Impact of Ni promotion on the hydrogenation pathways of phenanthrene on $\mathrm{MoS}_{2} / \gamma-\mathrm{Al}_{2} \mathrm{O}_{3}$, J. Catal. 352 (2017) 171-181. doi:10.1016/j.jcat.2017.05.003.

[42] Y. Romero, F. Richard, S. Brunet, Hydrodeoxygenation of 2-ethylphenol as a model compound of bio-crude over sulfided Mo-based catalysts: Promoting effect and reaction mechanism, Appl. Catal. B Environ. 98 (2010) 213-223. doi:10.1016/j.apcatb.2010.05.031.

[43] A.V. Bridgwater, Review of fast pyrolysis of biomass and product upgrading, Biomass and Bioenergy. 38 (2012) 68-94. doi:10.1016/j.biombioe.2011.01.048.

[44] D.C. Dayton, J. Carpenter, J. Farmer, B. Turk, R. Gupta, Biomass hydropyrolysis in a pressurized fluidized bed reactor, Energy and Fuels. 27 (2013) 3778-3785. doi:10.1021/ef400355t.

[45] M. Badawi, J.F. Paul, S. Cristol, E. Payen, Y. Romero, F. Richard, S. Brunet, D. Lambert, X. Portier, a. Popov, E. Kondratieva, J.M. Goupil, J. El Fallah, J.P. Gilson, L. Mariey, a. Travert, F. Maugé, Effect of water on the stability of Mo and CoMo hydrodeoxygenation catalysts: A combined experimental and DFT study, J. Catal. 282 (2011) 155-164. doi:10.1016/j.jcat.2011.06.006.

[46] M. Badawi, S. Cristol, J.-F. Paul, E. Payen, DFT study of furan adsorption over stable molybdenum sulfide catalyst under HDO conditions, C.R. Chim. 12 (2009) 754-761. doi:10.1016/j.crci.2008.10.023.

[47] A. Gaur, T.M.H. Dabros, M. Høj, A. Boubnov, T. Prüssmann, J. Jelic, F. Studt, A.D. Jensen, J.-D. Grunwaldt, Probing the active sites of $\mathrm{MoS}_{2}$ based hydrotreating catalysts using modulation excitation spectroscopy, ACS Catal. 9 (2019) 2568-2579. doi:10.1021/acscatal.8b04778.

[48] J.V. Lauritsen, F. Besenbacher, Atom-resolved scanning tunneling microscopy investigations of molecular adsorption on $\mathrm{MoS}_{2}$ and CoMoS hydrodesulfurization catalysts, J. Catal. 328 (2015) 49-58. doi:10.1016/j.jcat.2014.12.034. 
[49] N.-Y. Topsøe, H. Topsøe, FTIR studies of $\mathrm{Mo} / \mathrm{Al}_{2} \mathrm{O}_{3}$-based catalysts. II. Evidence for the presence of SH groups and their role in acidity and activity, J. Catal. 139 (1993) 641-651. doi:10.1006/jcat.1993.1056.

[50] K. Kolmetz, A. Jaya, KLM Technology Group, Hydrotreating (Engineering Design Guideline), Johor Bahru, 2013. http://kolmetz.com/pdf/EDG/ENGINEERING DESIGN GUIDELINE-HYDROTREATING Rev 02 web.pdf. (accessed March 20, 2019).

[51] R.H. Venderbosch, A.R. Ardiyanti, J. Wildschut, A. Oasmaa, H.J. Heeres, Stabilization of biomass-derived pyrolysis oils, J. Chem. Technol. Biotechnol. 85 (2010) 674-686. doi:10.1002/jctb.2354.

[52] K.C. Kwon, H. Mayfield, T. Marolla, B. Nichols, M. Mashburn, Catalytic deoxygenation of liquid biomass for hydrocarbon fuels, Renew. Energy. 36 (2011) 907-915. doi:10.1016/j.renene.2010.09.004.

[53] P.A. Spevack, N.S. McIntyre, A Raman and XPS investigation of supported molybdenum oxide thin films. 2. Reactions with hydrogen sulfide, J. Phys. Chem. 97 (1993) 11031-11036. doi:10.1021/j100144a021.

[54] G.L. Schrader, C.P. Cheng, In situ laser raman spectroscopy of the sulfiding of $\mathrm{Mo} / \gamma-\mathrm{Al}_{2} \mathrm{O}_{3}$ catalysts, J. Catal. 80 (1983) 369-385. doi:10.1016/0021-9517(83)90262-2.

[55] C.H. Chang, S.S. Chan, Infrared and raman studies of amorphous $\mathrm{MoS}_{3}$ and poorly crystalline $\mathrm{MoS}_{2}$, J. Catal. 72 (1981) 139-148. doi:10.1016/0021-9517(81)90085-3.

[56] E. Laurent, B. Delmon, Influence of water in the deactivation of a sulfided $\mathrm{NiMo} / \gamma-\mathrm{Al}_{2} \mathrm{O}_{3}$ catalyst during hydrodeoxygenation, J. Catal. 146 (1994) 281-291. doi:10.1016/0021-9517(94)90032-9.

[57] J.J.H.B. Sattler, A.M. Beale, B.M. Weckhuysen, Operando Raman spectroscopy study on the deactivation of $\mathrm{Pt} / \mathrm{Al}_{2} \mathrm{O}_{3}$ and $\mathrm{Pt}-\mathrm{Sn} / \mathrm{Al}_{2} \mathrm{O}_{3}$ propane dehydrogenation catalysts, Phys. Chem. Chem. Phys. 15 (2013) 1209512103. doi:10.1039/c3cp50646k.

[58] A. Sadezky, H. Muckenhuber, H. Grothe, R. Niessner, U. Pöschl, Raman microspectroscopy of soot and related carbonaceous materials: Spectral analysis and structural information, Carbon N. Y. 43 (2005) 17311742. doi:10.1016/j.carbon.2005.02.018.

[59] FIZ Karlsruhe, ICSD FIZ Karlsruhe. ICSD Web Database, (n.d.). https://icsd.fizkarlsruhe.de/search/basic.xhtml (accessed November 3, 2017).

Table 1 Composition and properties of as-prepared catalysts (oxide phase precursors). SSA: Specific surface area.

\begin{tabular}{|c|c|c|c|c|c|}
\hline Catalyst & Mo & $\begin{array}{l}\text { Promoter } \\
\text { (Ni or Co) }\end{array}$ & Promoter/Mo & Mo load & $\begin{array}{l}\text { BET } \\
\text { SSA }\end{array}$ \\
\hline & [wt\%] & [wt\%] & [molar] & {$\left[\right.$ atoms $\left./ \mathbf{n m}^{2}\right]$} & {$\left[\mathrm{m}^{2} / \mathrm{g}\right]$} \\
\hline NiMo\#L & 0.83 & 0.17 & 0.34 & 0.85 & 80 \\
\hline NiMo\#H & 2.83 & 0.58 & 0.34 & 3.0 & 97 \\
\hline $\mathrm{NiMo \# H}^{\mathrm{a}}$ & 3.33 & 0.66 & 0.33 & 3.7 & 77 \\
\hline CoMo\#L & 0.88 & 0.16 & 0.30 & 0.91 & 79 \\
\hline CoMo\#H & 3.28 & 0.59 & 0.29 & 3.5 & 73 \\
\hline CoMo\#H $^{\mathrm{a}}$ & 3.37 & 0.58 & 0.28 & 3.7 & 70 \\
\hline
\end{tabular}

a) Only used for XRD characterization. 


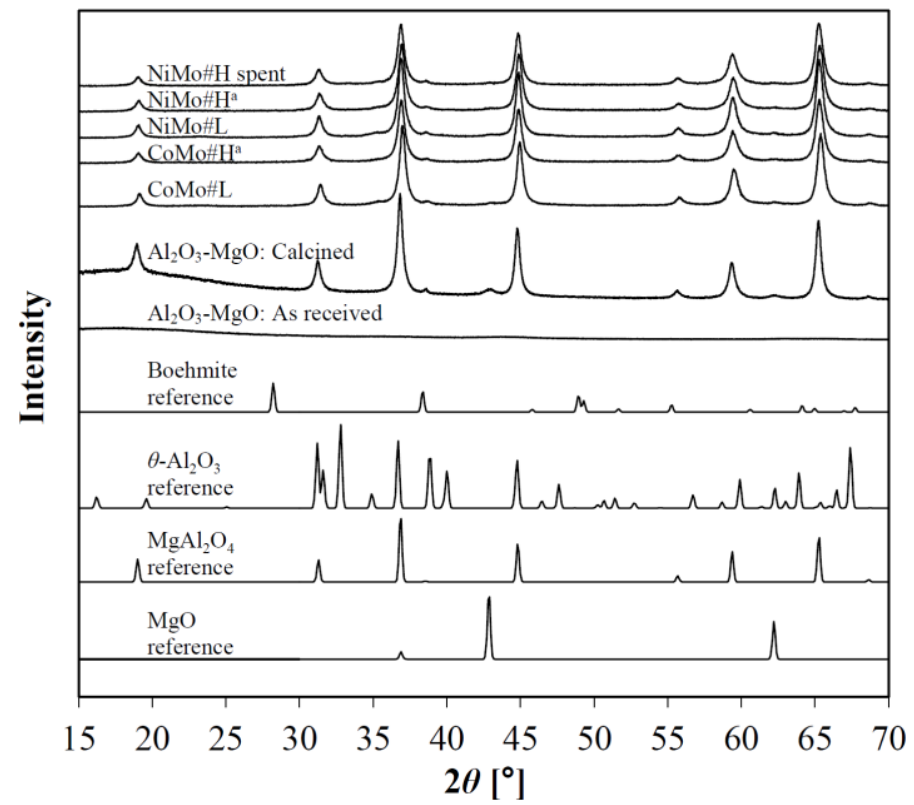

Fig. 1 XRD diffractograms of the support material in its as-received and calcined state, of the oxide phase catalyst precursors (Table 1), and of a spent NiMo\#H catalyst (Table 3). References for $\gamma-\mathrm{Al}_{2} \mathrm{O}_{3}, \mathrm{MgAl}_{2} \mathrm{O}_{4}, \mathrm{MgO}$, and boehmite (AlOOH) have been inserted (from the ICSD Web Database [59], collection codes 82504, 39161, 9863, and 36340).

Table 2 Concentration of acid sites ( $\mathrm{NH}_{3}-\mathrm{TPD}$ ) for the support material, its precursor, and a $\gamma-\mathrm{Al}_{2} \mathrm{O}_{3}$ sample (Puralox NWa 155 from Sasol). The mass of each sample was chosen to achieve a constant total surface area of $45 \mathrm{~m}^{2}$.

\begin{tabular}{|c|c|c|c|}
\hline \multirow[t]{2}{*}{ Material } & \multirow{2}{*}{$\begin{array}{l}\text { SSA } \\
(\text { BET) } \\
{\left[\mathrm{m}^{2} / \mathrm{g}\right]}\end{array}$} & \multicolumn{2}{|c|}{$\mathrm{NH}_{3}$ uptake } \\
\hline & & {$\left[\mu \mathrm{mol} / \mathbf{m}^{2}\right]$} & {$[\mathrm{mmol} / \mathrm{g}]$} \\
\hline $\mathrm{MgAl}_{2} \mathrm{O}_{4}$ & 60 & 1.137 & 0.068 \\
\hline $\begin{array}{l}\mathrm{MgAl}_{2} \mathrm{O}_{4} \\
\text { precursor } \\
\left(\mathrm{Al}_{2} \mathrm{O}_{3}-\mathrm{MgO}\right)\end{array}$ & 266 & 0.594 & 0.158 \\
\hline$\gamma-\mathrm{Al}_{2} \mathrm{O}_{3}$ & 153 & 0.993 & 0.152 \\
\hline
\end{tabular}




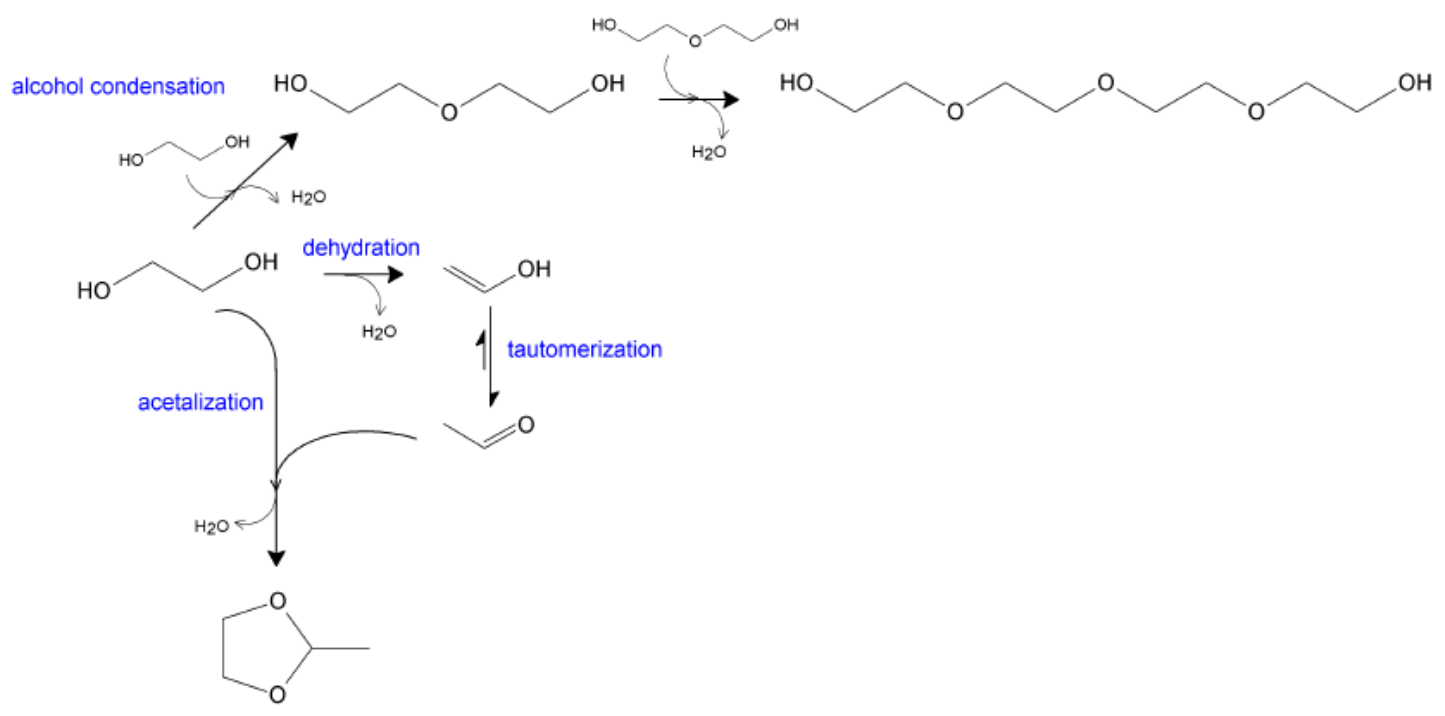

Fig. 2 Proposed reaction scheme for formation of common coupling products detected in the conversion of ethylene glycol over $\mathrm{MgAl}_{2} \mathrm{O}_{4}$. 

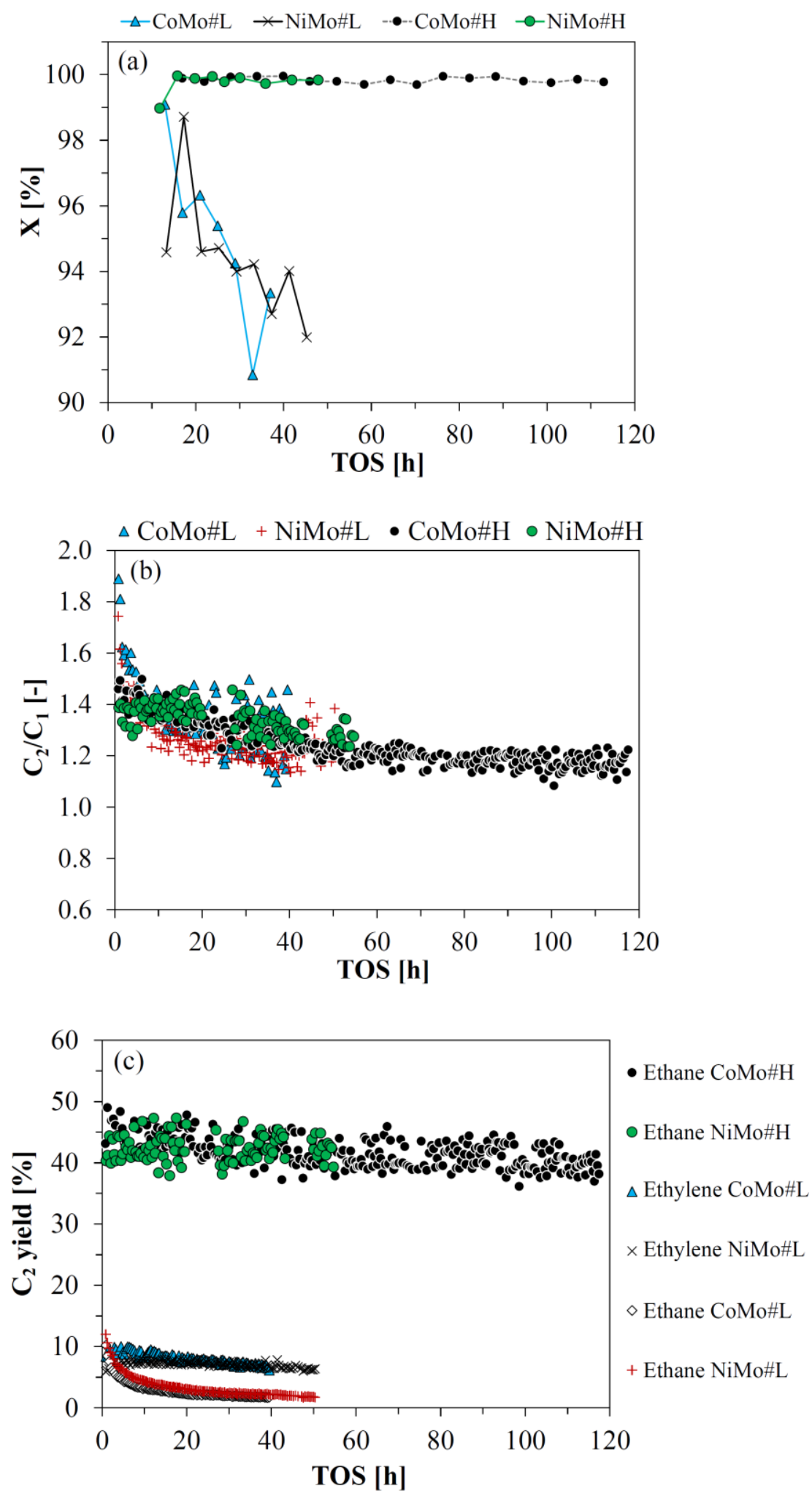

Fig. 3 Results from the conversion of ethylene glycol over prepared catalysts $(4.0 \mathrm{~g})$ at $\mathrm{WHSV} \mathrm{EG}_{2} \approx 2 \mathrm{~h}^{-1}$. (a) Conversion, $\mathrm{X}$, (b) Carbon based yield ratio of $\mathrm{C}_{2} / \mathrm{C}_{1}$ products, (c) Yield of $\mathrm{C}_{2}$ compounds. $\mathrm{C}_{2}$ : ethane and ethylene, $\mathrm{C}_{1}$ : $\mathrm{CO}_{1} \mathrm{CO}_{2}$, and $\mathrm{CH}_{4}$. The fluctuating gas yields at $100 \%$ conversion (NiMo\#H and $\mathrm{CoMo \# H)} \mathrm{reflect} \mathrm{the} \mathrm{fluctuations} \mathrm{in} \mathrm{the} \mathrm{liquid} \mathrm{feed} \mathrm{flow.} \mathrm{No} \mathrm{ethylene} \mathrm{was}$ detected over high loading catalysts. 


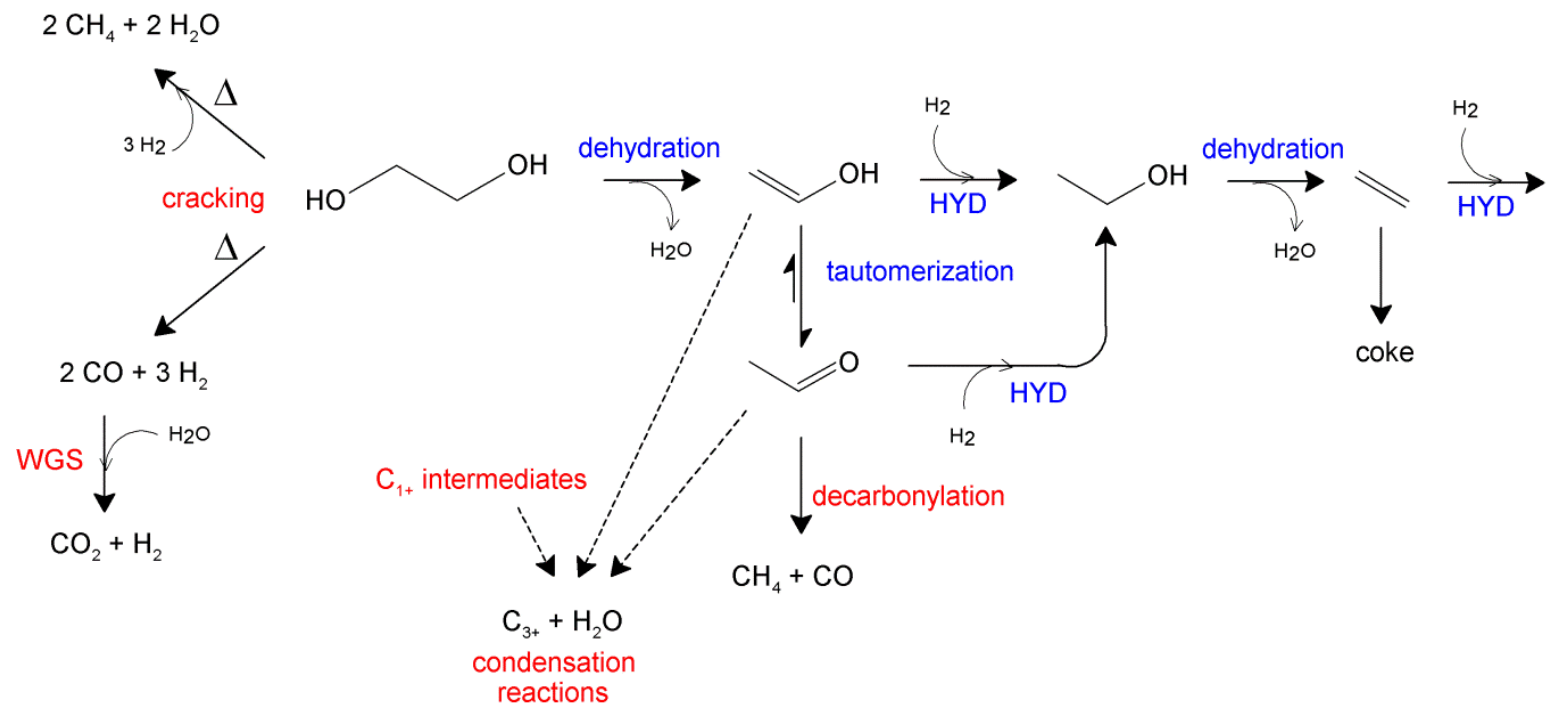

Fig. 4 Proposed reaction scheme for the conversion of ethylene glycol into $\mathrm{C}_{1}, \mathrm{C}_{2}$, and $\mathrm{C}_{3+}$ products including target reactions (blue) and side reactions (red).

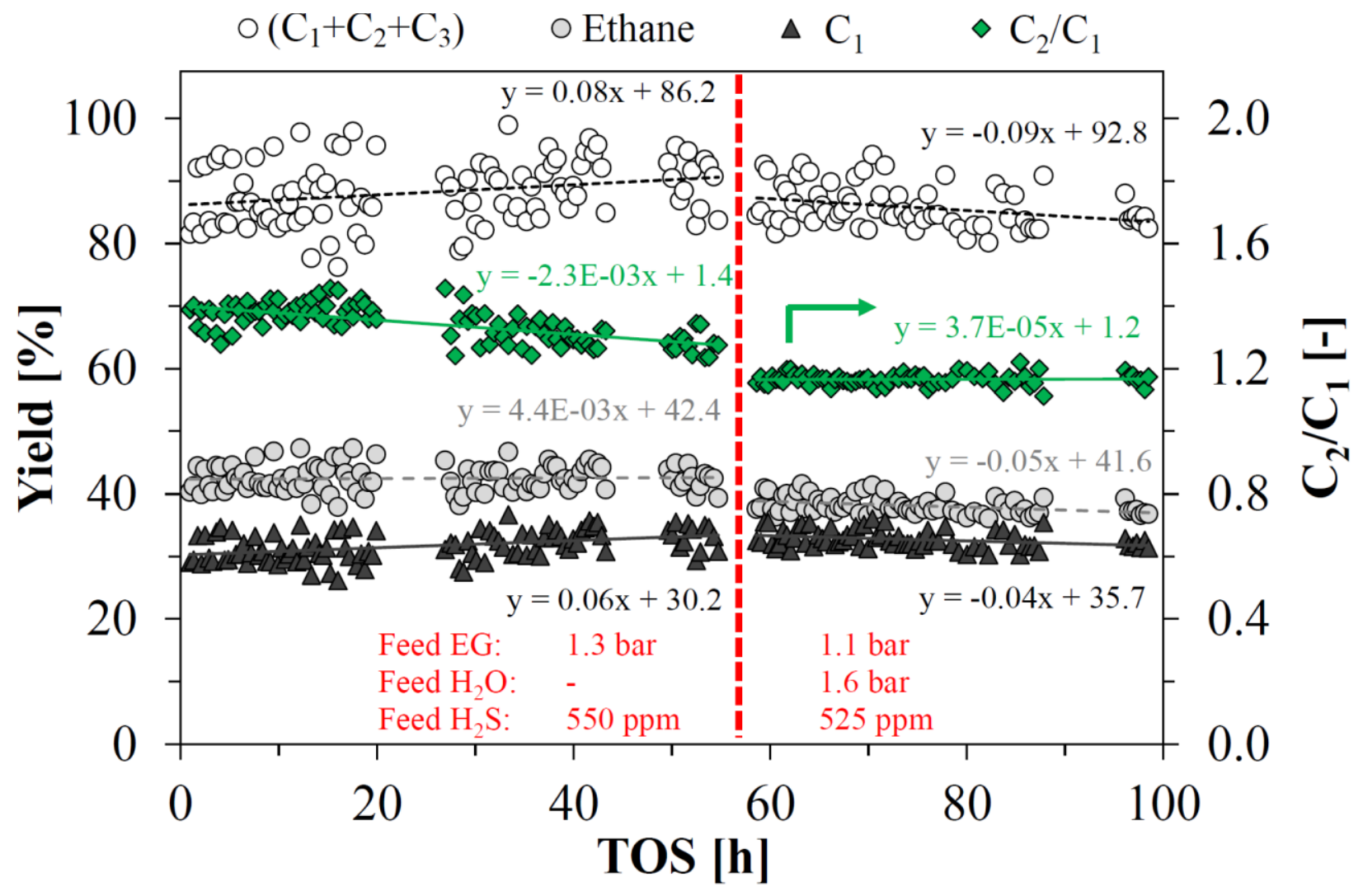

Fig. 5 Gas product yields from conversion of ethylene glycol over NiMo\#H $(4.0 \mathrm{~g})$ at WHSVEG $\approx 2 \mathrm{~h}^{-1}$. The first $50 \mathrm{~h}$ on stream are also represented in Fig. 3. No ethylene or propylene was detected. 


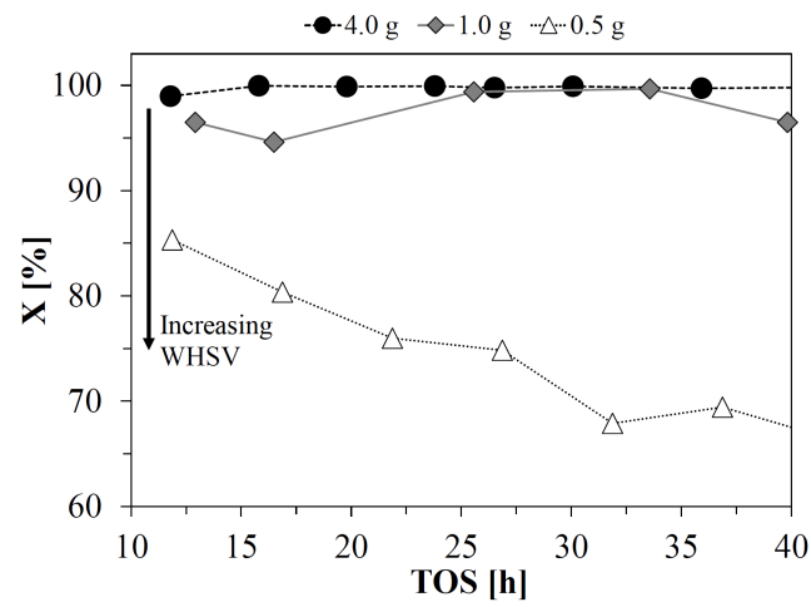

Fig. 6 Conversion, $\mathrm{X}$, of ethylene glycol over NiMo\#H at $\mathrm{WHSV}_{\mathrm{EG}}=2,9$, and $18 \mathrm{~h}^{-1} \mathrm{using} 4.0,1.0$, and $0.5 \mathrm{~g}$ of catalyst and a co-feed of $550 \mathrm{ppm} \mathrm{H}_{2} \mathrm{~S}$.
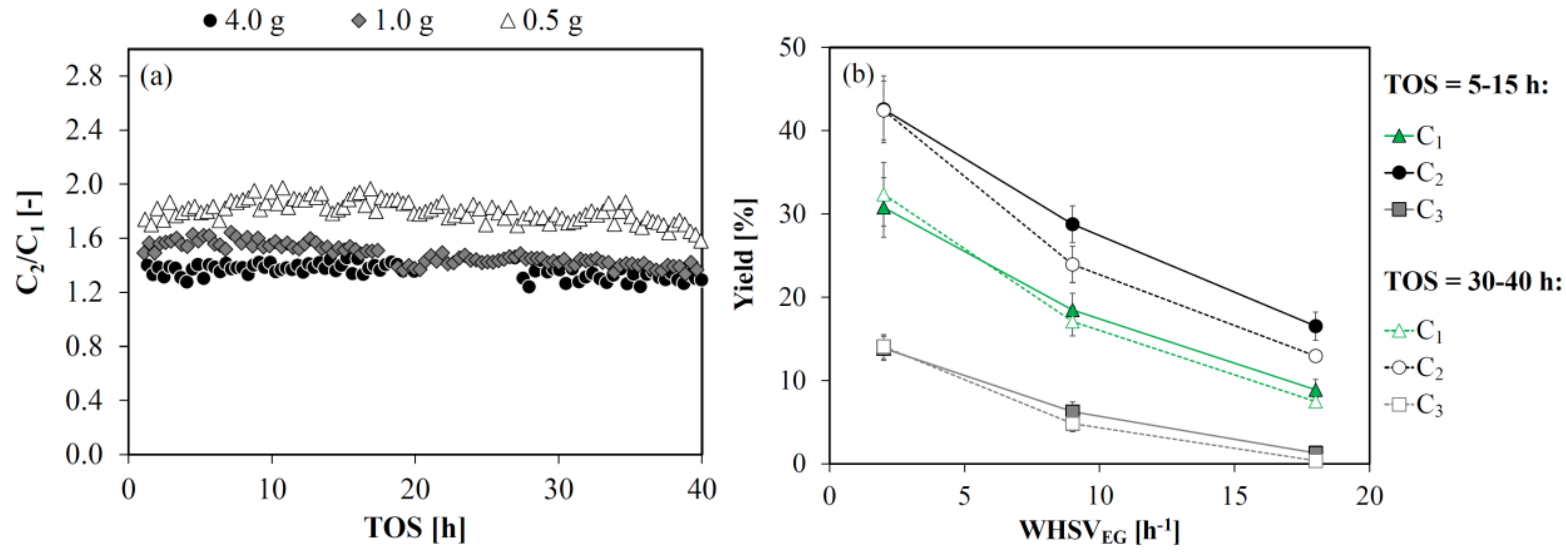

Fig. 7 (a) Carbon based yield ratio of $\mathrm{C}_{2} / \mathrm{C}_{1}$ products, from the conversion of ethylene glycol over NiMo\#H at $\mathrm{WHSV} \mathrm{EG}_{\mathrm{E}}=2,9$, and $18 \mathrm{~h}^{-1}$ using 4.0, 1.0, and $0.5 \mathrm{~g}$ of catalyst and a co-feed of $550 \mathrm{ppm} \mathrm{H}_{2} \mathrm{~S}$. (b) Average gas product yields at 5-15 and 30-40 h on stream as a function of WHSVEG. Error bars: two times the standard deviation.

Table 3 Composition of spent catalysts exposed to varying $\mathrm{H}_{2} \mathrm{~S}$ concentration, and $\mathrm{WHSV} \mathrm{EG}_{\mathrm{E}}=2 \mathrm{~h}^{-1}$. For fresh catalyst composition, see Table 1.

\begin{tabular}{|l|l|l|l|l|l|l|l|l|}
\hline Catalyst & TOS & Mo & $\begin{array}{l}\text { Promoter } \\
\text { (Ni or Co) }\end{array}$ & Promoter/Mo & S & $\mathbf{C}$ & S/Mo & C/TOS \\
\hline & {$[\mathbf{h}]$} & {$[\mathbf{w t} \%]$} & {$[\mathbf{w t} \%]$} & {$[$ molar $]$} & {$[\mathbf{w t \%}]$} & {$[\mathbf{w t} \%]$} & {$[\mathbf{m o l a r}]$} & {$[\mathbf{w t \% / h ]}$} \\
\hline NiMo\#L & 106 & 0.76 & 0.11 & 0.24 & 0.73 & 9.5 & 2.87 & 0.09 \\
\hline NiMo\#H & $99^{\mathrm{a}}$ & 2.91 & 0.50 & 0.28 & 2.24 & 3.5 & 2.30 & 0.04 \\
\hline CoMo\#L & 91 & 0.73 & 0.11 & 0.25 & 0.70 & 9.1 & 2.87 & 0.10 \\
\hline CoMo\#H & 172 & 2.56 & 0.44 & 0.28 & 1.77 & 8.8 & 2.07 & 0.05 \\
\hline
\end{tabular}

a) Water was added to the feed after $\sim 55 \mathrm{~h}$ on stream. 


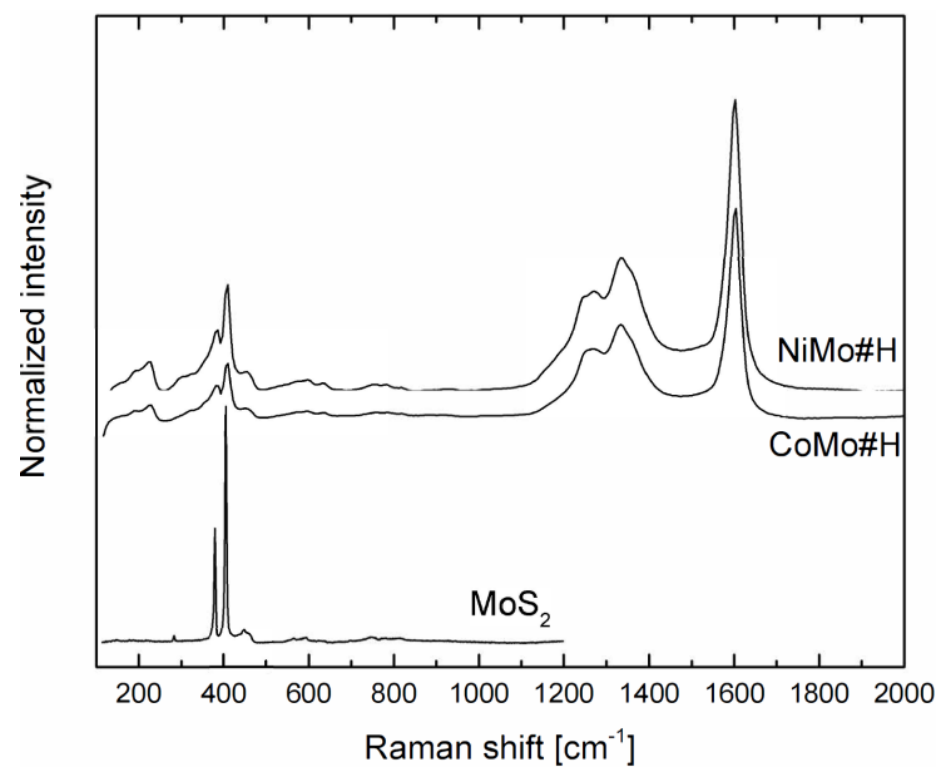

Fig. 8 Baseline corrected Raman spectra of spent NiMo\#H and CoMo\#H along with a MoS 2 reference (Sigma-Aldrich $99 \%)$. 